\title{
Modeling of a System Dynamics of Fisherman Insurance Demand in Malang District
}

\author{
Lina Asmara Wati ${ }^{1 *}$, Riski Agung Lestariadi ${ }^{1}$ and Supriyadi Supriyadi ${ }^{2}$ \\ ${ }^{1}$ Fisheries Agrobusiness, Faculty of Fisheries and Marine Sciences, Universitas Brawijaya, Malang, \\ 65145 Indonesia \\ ${ }^{2}$ Socio-Economy Fisheries, Faculty of Fisheries and Marine Science, Universitas Brawijaya, Kediri \\ Campus, 64111 Indonesia
}

*Correspondence :

linaasmara@ub.ac.id

Received : 2020-11-07

Accepted : 2021-03-09

Keywords :

Demand, Fisherman insurance, Demand system dynamics, System dynamics

\begin{abstract}
Fisherman Insurance Premium Assistance is applied to all coastal areas in Indonesia. In Malang Regency, it just started in 2016 through JASINDO, so many fishermen still do not fully understand the benefits against possible risks. Therefore, it is necessary to study the dynamics of the fisherman insurance system focusing on producing a model of insurance demand and the projection of the demand and growth of fisherman insurance in the future. The method used in this research was a series of system dynamics modeling. The results of the validity test in this study indicate the mean comparison and error variance is the following: fisherman insurance program $=4.8 \%$ and $6.01 \%$; fishermen's value $=4.0 \%$ and $21.55 \%$ and premium assistance $=3.9 \%$ and $12.17 \%$. Moreover, the structural and parametric scenario analysis results show the average value of the increase in tourists: Scenario 1 Structural: Premium assistance $=602$ fishermen, Scenario 2 Structural: 394 fishermen, Parametric Scenario 1 - Optimistic $=578$ fishermen, Parametric Scenario 2 - Most Likely $=289$ fishermen, and Parametric Scenario 3 - Pessimistic $=201$ fishermen. However, the projection of the demand for fisherman insurance in 2021-2029 has not shown the expected results. The largest number of demands is 421 and the smallest is 321 in 2026. Moreover, after several simulations, the study found the most possible simulation to be carried out and to have a significant, stable effect on the results desired by the government, which is through premium assistance. If at least insurance premium assistance of Rp. 118,000x109 can be given annually, it will be able to generate a fisherman insurance demand at a minimum of 500 .
\end{abstract}

\section{INTRODUCTION}

The insurance development nowadays is marked by the increasing number of types of insurance in Indonesia. Insurance is a service in society that provides compensation, which is obtained from the premiums collected if the risk occurs to members who participate in the established plan (Rusman, 2018). The insurance company has the main function of transfer of risk, collection of funds and premiums that are balanced, loss prevention, loss control, social benefits, and savings. Common types of insurance in Indonesia include life, health, 
education, vehicles, property, travel and marine.

Marine insurance is insurance that provides guarantees or protection against financial losses suffered by the shipowner or other parties dealing with transportation, as a result of loss or damage incurred to the ship, cargo, or freight and other costs incurred by sea hazards or risks guaranteed in the agreement (Rusman, 2016). However, out of several types of existing insurance, very few insurance companies have programs to protect workers; one of the examples is fishermen's insurance. Insurance companies are reluctant to take more risks because fishing is a job that is prone to problems, and it is very difficult to prove facts that occur.

The safety of fishermen must be a priority in fishing activities because the role of fishermen will also determine the success of Indonesian exports. According to Wati and Primyastanto (2018), one of the most contributing things is the moratorium activity through IUU which is implemented through the Ministry of Maritime Affairs and Fisheries of the Republic of Indonesia. This activity appears to play a significant role in encouraging better Indonesian fishery exports. Because Indonesia has the potential for high fisheries resources, which means that it must be directly proportional to the results of our fishery exports, besides that we also have to be successful in meeting the needs of domestic fisheries.

A job as a fisherman should get special attention from the government to get protection. Regarding the importance of protection for fishermen (Law of the Republic of Indonesia Number 7 of 2016). This Law is implemented by the government by creating Fishermen
Insurance Premium Assistance (BPAN). This program was created to ensure better fishermen's activities in the fishing business so that the rights and obligations of fishermen are clear, and the fishermen will be protected in their fishing business activities (Law of the Republic of Indonesia Number 7 of 2016). BPAN is insurance for fishermen where the monthly premium is borne by the government of Rp. 175,000 with a benefit value from Rp. $20,000,000$ to $\mathrm{Rp}$. $200,000,000$.

Fishermen Insurance Premium Assistance is applied to all coastal areas in Indonesia, one of which is the Malang Regency. Malang Regency has six districts with the majority of people working as fishermen because they are located in a coastal area.

In this research, the researcher determined the limits of the research object only in the Sumbermanjing Wetan District because the number of small fishermen in that district is larger so that a more accurate model could be produced. The purpose of this research is to make dynamic modeling of the demand for fishermen insurance in Sumbermanjing Wetan District, Malang and to analyze the projection of fishermen insurance in Sumbermanjing Wetan District, Malang.

\section{METHODOLOGY}

\section{Place and Time}

This research was conducted in Sumbermanjing Wetan District, Malang Regency, East Java in April - October 2020.

\section{Research Design}

The steps for obtaining modeling by the needs of fishermen are presented in Figure 1. 
Figure 1. Method of analysis.

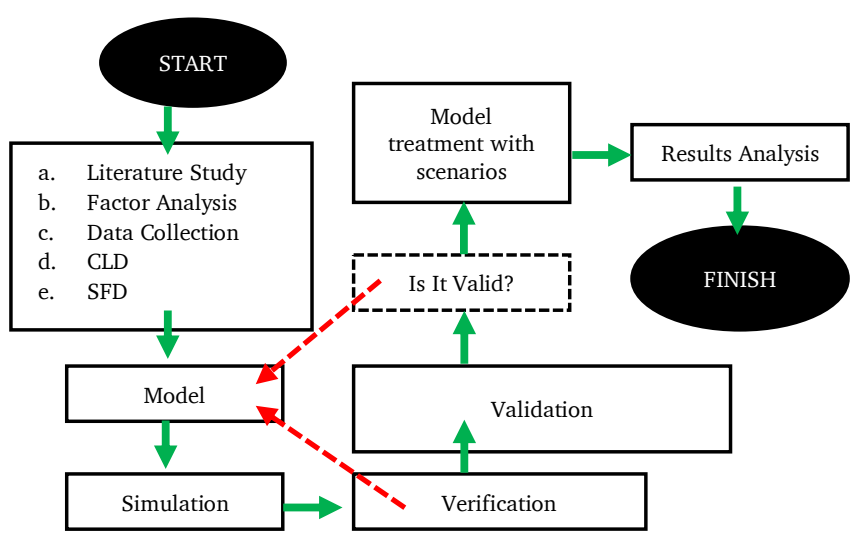

\section{System Dynamics Modeling Concepts}

Analysis of a system requires a method that considers each component in the system, especially on issues of a natural complex. In these complex problems, tools can show you how the condition of the observation system in a comprehensive manner, namely the dynamic system.

System dynamics is a method of problem analysis where time is a factor important and includes understanding how a system can be maintained from disturbances outside the system or made by the objectives of the system modeling created (Coyle, 1997). It is a methodology for understanding a complex problem. This methodology focuses on policies and how these policies determine the behavior of problems that can be modeled by a dynamic system (Richardson and Pugh III, 1997).

System dynamics is a method of qualitative description, understanding, and system analysis complex in the scope of processes, information, and organizational structures, that eases the simulation of quantitative modeling and policy analysis of the structural systems and control (Wolstenholme, 1989). It is an area for understanding how things change accordingly time. This system is formed by differential equations used for biophysical problems that are formulated as a state in the future that depends on the current situation (Forrester, 1999).
Based on the above definitions, a dynamic system is a methodology to analyze the components of a system with the time component as a factor important by using causal relations and the basis of logic and mathematics, time delays, and feedback loops. The use of this method is often used for evaluating and improving policies in a system. In system dynamics, the complexity of the system is realized based on three aspects, namely delay in between a causal relationship, the existence of feedback, and several stocks (Nuhoğlu and Nuhoğlu, 2007). System dynamics tries to learn part of the whole system but does not ignore its environmental monitoring system. Variables that do not have a significant effect on the observation system will be a limitation in the dynamic system analysis so that the system observation becomes a closed system.

\section{Work Procedure}

First of all, the conditions in the field were carried out, and then the data were taken to be used as significant variables as well as supporting variables that influence each other for the modeling of the system to be simulated. The variables that are assumed to be included in this model are fishing income, fishermen's expenses, insurance demand, insurance offers, and population data. The required data were obtained in various ways, namely: direct observation of all fishermen in Sumbermanjing Wetan district and interviews with related agencies as well as 
from existing documentation such as monthly reports, annual reports, and surveys from the year 2016-2019. Moreover, the data collection was carried out for fishermen who have participated in the insurance program (Jasindo).

The next step was to make a conceptual model described using a Causal Loop Diagram (CLD). This causal diagram was used to visualize the system in general which would be simulated by the dynamic system method through the visible components. These components become variables, parameters and constants that are interdependent and affect the behavior of the system.

The causal diagram was then translated into a dynamic system model which was depicted through the stock and flow diagrams which were formed through four components, namely: system, feedback, level and rate. Afterward, the equation of each variable as a formulation in the model was determined by understanding and testing the consistency of the model whether it was following the objectives and limitations of the system being made.

The validation process was also required in building a model. Validation serves to prove whether the model created represents the real system. There were two ways to test the model, namely:

a. Mean Comparison

$E 1=\frac{|\bar{S}-\bar{A}|}{\bar{A}}$

Where:

$S=$ Average Value of Simulation Results

A = Data Mean Value

model is considered valid if $\mathrm{E} 1 \leq 5 \%$

b. Amplitude Variation Comparison (\% Error Variance)

$E 2=\frac{s s-s a}{s a}$

Where:

Ss $=$ Standard deviation of the model

$\mathrm{Sa}=$ Standard Deviation of Data

The model is considered valid if E2 $\leq$ $30 \%$.

Verification was done by checking the model and unit on the model using the facilities at Vensim. Model validation was carried out by two methods of testing, namely model validation using a statistical test of mean comparison and model validation using a comparison test of amplitude variation (\% error variance) (Barlas, 1989).

\section{Data Analysis}

The analysis and discussion that have been carried out were concluded to obtain the results, which later would be given suggestions related to the modeling of the fishermen insurance demand system and further research.

To ensure and prove the appropriate simulation model and represents a real system then the model testing mechanism or model validation. Several testing techniques can be implemented on the dynamic systems model.

Limit Adequacy Test is used to assess the adequacy of the model constraints against the destination. This test is carried out by referring to the cause-and-effect diagram. When limitation the model has been formed through a cause-and-effect diagram, then it is tested on whether the system variables have a significant effect on the objectives model. If the variable does not have a significant effect, it does not need to be put in the model. A test for the adequacy of this limitation can also be performed by testing whether the recommendation policy given will change with extending the boundaries of the model (Sterman et al., 2007).

Model Structure Test is used to test the extent to which the similarity of the model structure approximates the real system structure. The similarity is measured with the extent to which the interaction of the variables in the model can mimic the interaction of the system. There are two types of structural validity, namely construction validity and structural stability. Construction validity is the belief that the model construction is scientifically valid or supported/accepted academically. Meanwhile, the stability of the structure is enforceable or the 
robustness of the structure in the time dimension (Muhammadi et al., 2001).

Model parameter test was conducted to determine the consistency of the existing parameter values. This test is done by testing the behavior of the corresponding simulation result parameter values or not with the relationship described through the conceptual model or CLD. There are two steps in testing the model parameters, namely the validation of the input variables and logical validation of the relationship between variables. Input variable validation is performed by comparing historical data and data entered into the model. Logical validation between variables is done by checking the logic in the system is good input or output (Suryani et al., 2010).

Testing of extreme conditions can be carried out in two ways, namely by checking directly in the equation model and through simulation. Direct check on the equation model is done by checking the output of the equation if The input of the equation is given the maximum and minimum value what the output is the results are still feasible and feasible or not (Sushil, 1993).

The model/replication behavior test is conducted to find out how the model behaves is the same as the real condition behavior. Testing is done with compares the output of a replicated number of simulations and the actual data on the system real (Barlas, 1989).

\section{RESULTS AND DISCUSSION Model Design}

The simulation methods used in this dynamic system in the early stages of planning this model were the making of CLD and SFD. Modeling and simulation in this study were used to model the variables that affect the demand for fishermen's insurance in Malang Regency. In the variable modeling in the form of CLD and SFD making, simulations at each level (basic variables) that affect the outflow and inflow variables in the SFD were also carried out.

Based on the results of the research, the demand for fishermen insurance in Malang Regency is influenced by: Total population affected by the total number of births and deaths in a given area, BPAN which is influenced by insurance demand and insurance offers, and the net value of NTN (Fisherman Exchange Rate) which is influenced by the income of marine products and expenditure on living necessities.

At this stage, the process of processing data from the survey results and factor analysis from the required data was carried out. The data processing aimed to formulate the relationship between each variable that affects the demand for fishermen insurance in Malang Regency. This relationship will provide an overview of the existing conditions in an insurance demand model. Several stages used in developing the model in this research are as follows: CLD, SFD, Model verification, Model Validation, and Scenario Design.

\section{Causal Loop Diagram (CLD)}

The first step in making a dynamic system simulation was to formulate a model following the existing conditions of the fishermen's insurance demand in Malang Regency. The most important thing in making the CLD concept was to identify and connect each of the variables affecting the demand for fishermen insurance in Malang Regency.

CLD in Figure 2 shows that there are twenty-five variables related to the demand for fishermen insurance in Malang Regency. The followings are the influencing variables in this research: fishermen's ability, fishermen's needs, premium assistance, fishermen insurance rates, insurance quality, number of fishermen, DKP Role, Variable costs, Fixed costs, Claims, Private insurance with noncooperation with the government, Competitor insurance, Capture fisheries business development, Increased multiplier effect, Fisherman institutions, 
Catch, Net value of fishermen's income, NTN Net value, Regional GDP, Government budget for fishermen's welfare, Total population, Death, Emigration, Immigration, and Birth.

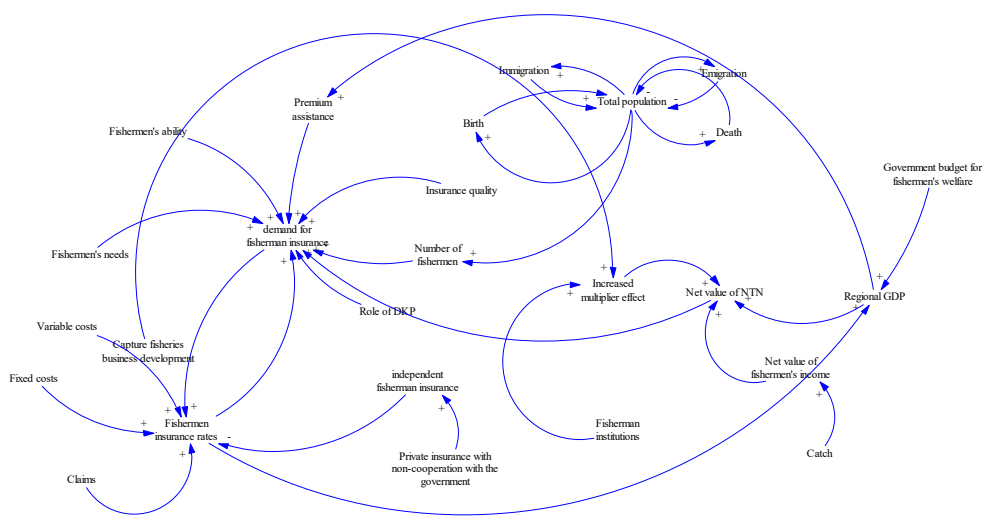

Figure 2. Causal Loop Diagram of Insurance Demand in Malang Regency.

The CLD in Figure 2 explains that in the demand for fishermen insurance in Malang Regency, the most important variables are the NTN and the fisherman insurance rate. NTN is greatly influenced by the catch which becomes the income of primary fishermen in calculating the net value of NTN and the living needs of fishermen's families. Moreover, the fisherman insurance rate is an important variable in the demand for fisherman insurance. The influencing variables are: variable costs, fixed costs, claims, other insurance (competitors), and the number of insurance demands.

CLD can be used to record a model that represents the linkages and feedback processes in the system (Yuen and Chan, 2010). In addition, Kiani et al. (2009) stated that the main goal of CLD is to describe the causal hypothesis, thus making a presentation of the internal problem structure aggregate form.

One of the determining Regional Performance Indicators is the NTN. The fisherman exchange rate is based on the definition from BPS is the comparison between the price index received by the fishermen and the price index paid by the fishermen (Marine and Fisheries Department of Trenggalek Regency, 2019). Conceptually, NTN states the level of exchangeability of goods (products) produced by fishermen for goods/services needed for household consumption and purposes in the fishery production process. NTN> 100 means that fishermen are experiencing a surplus. In this case, the increase in production prices is higher than the increase in consumer prices. The income of fishermen is also higher than their expenses. Moreover, NTN $=100$ means that the fishermen experience a breakeven point. Meanwhile, NTN $<100$ means that fishermen have a deficit, and fishermen's income decreases and is smaller than their expenditure.

\section{Stock Flow Diagram (SFD) with Several Sub Models}

Data modeling and the making of flow diagrams in this research produce three models of stock flow diagrams. Data modeling was made to analyze behavior patterns, influences and relationships between variables in the simulations that would be carried out to determine the suitability of the model with its real behavior/effects in the field (in real conditions). The implementation of data modeling that has been successfully created is described in the causal loop diagram in Figure 2. After making the causal loop diagram, the next step was to do flow diagram modeling which would make it easier to describe simulations (to determine the role of several variables related to the demand of fisherman 
insurance in Malang Regency) and to make a model scenario.

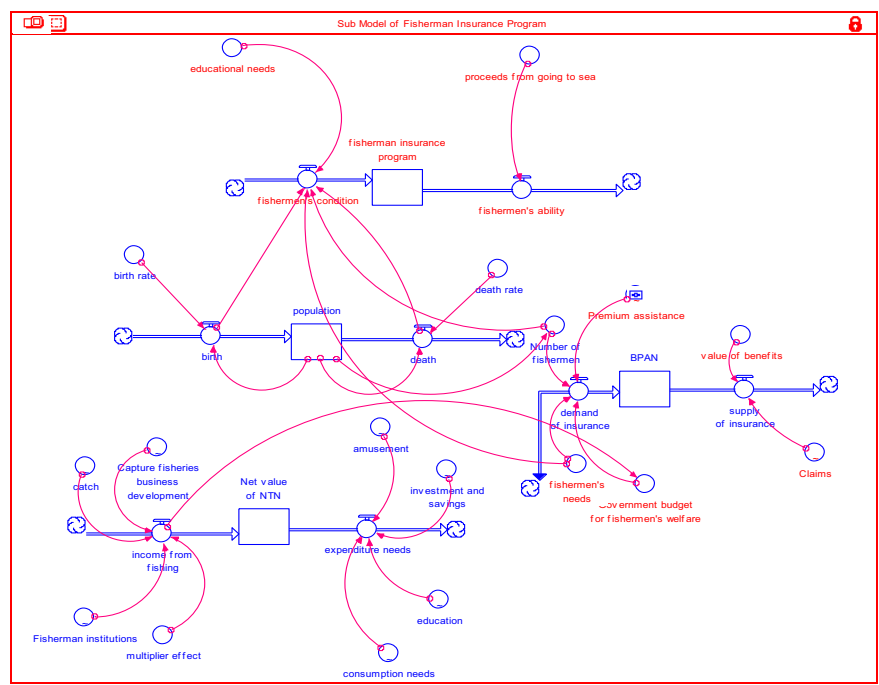

Figure 3. SFD Sub Model of Fisherman Insurance Program.

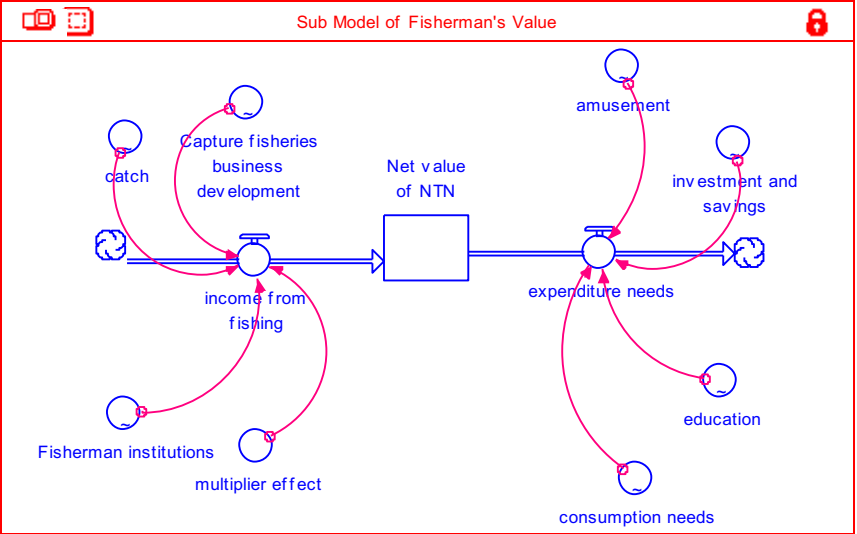

Figure 4. SFD Sub Model of Fisherman's Value.

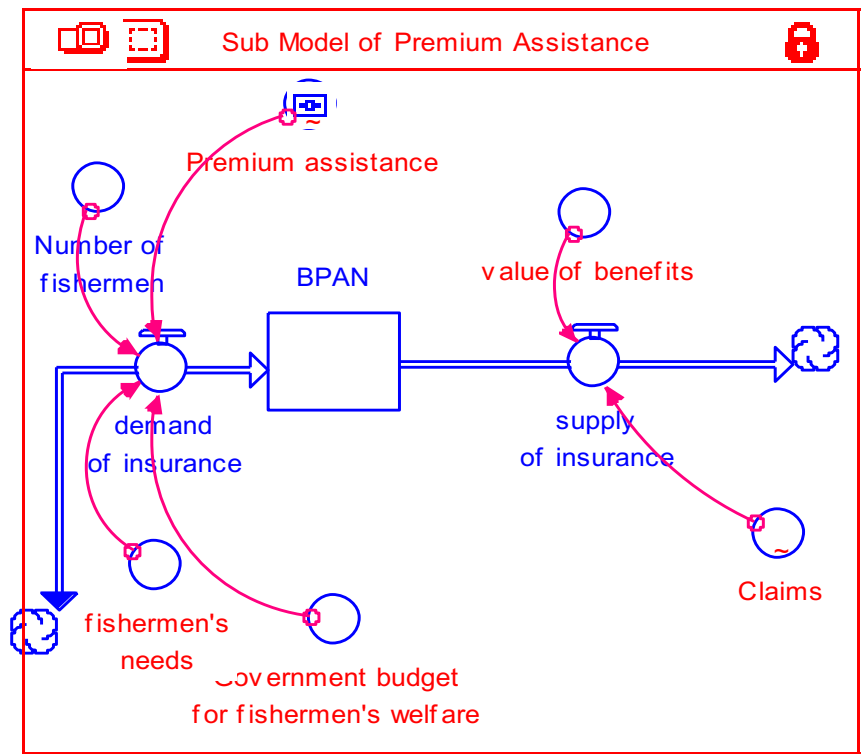

Figure 5. SFD Sub Model of Premium Assistance. 
Figures 3, 4, and 5 are the SFD sub models that the researchers created based on the needs of fishermen insurance demand and the variables are in accordance with existing theories and field conditions. Figure 3 shows the SFD sub model of the insurance program itself and is directly influenced by the conditions and capabilities of the fishermen's internal side (socio-economic conditions and fishermen's environment) and also from the external side (such as the role of local and national governments in giving attention to fishermen's welfare). Figure 4 illustrates the SFD sub model of the fisherman's value, and the fisherman exchange rate (NTN) the researchers would assess is the net value of the fisherman exchange rate.

This net value of NTN is directly related to the income of fishermen based on the catches of fishing and the expenses of fishermen in their daily life. Figure 5 depicts the SFD sub model of premium assistance. The researchers created this sub model based on the statements expressed by the fishermen during their field activities stating that their interest in participating in insurance would be higher if the government provides premium assistance facilities as it is greatly needed by the fishermen. BPAN (Fisherman Insurance Premium Assistance) has a direct influence on the demand and supply of the insurance itself.

Several pre-existing studies are related to variables that play an important role in the demand for fisherman insurance in Malang Regency. Thus, to find out the relationship between the number of insurance demands with the fisherman insurance program, fishermen's value, and premium assistance, in the next stage a double log regression analysis was conducted. The results of this analysis indicate that the number of demands for fisherman insurance becomes the dependent variable. Meanwhile, fisherman insurance program, fishermen's value, and premium assistance are independent variables. The correlation and elasticity values between the dependent and independent variables are shown in Table 1 below.

Table 1. Results of variable regression in the increase of tourism potential.

\begin{tabular}{lc}
\hline \multicolumn{1}{c}{ Variable } & Value \\
\hline $\mathrm{R}^{2}$ & 0.761 \\
Adjusted $\mathrm{R}^{2}$ & 0.745 \\
X Fisherman Insurance Program Variable & -0.621 \\
X Fishermen's Value Variable & -0.553 \\
$\mathrm{X}$ Premium Assistance Variable & 0.647 \\
\hline
\end{tabular}

\section{Verification and Validation}

Model verification is carried out to ensure that the Stella program used and the implementation of the conceptual model that has been made based on the research results do not have errors. At this verification stage, a check will be carried out on the Stella program and its implementation. In short, the verification process in this Stella program will be carried out when the model that has been created works and runs successfully.
Model validation is also carried out to ensure that the behavioral output of the variables in the model is accurate, under the facts in the field and can be reasonably accepted (scientific thinking analysis). One way that can be done is by doing a behavior pattern test. The process carried out in this test is to compare the results of the mean comparison and the variance error. A model is considered valid if the results of mean comparison $<5.0 \%$ and the error variance value $<30 \%$. The results of the validation test in this study are shown in Table 2 below. 
Table 2. Validation test.

\begin{tabular}{lll}
\hline Variable & Mean Comparison & Error Variance \\
\hline Fisherman Insurance Program & $4.8 \%$ & $6.01 \%$ \\
Fisherman's Value & $4.0 \%$ & $21.55 \%$ \\
Premium Assistance & $3.9 \%$ & $12.17 \%$ \\
\hline
\end{tabular}

\section{The Making of Scenarios and Result Analysis}

After verification and validation with the data of field result on the basic model and three sub models have been conducted, the next stage is to create several scenarios as a form of development from the results of several models that have been made. In this study, there were two scenarios in the system simulation, namely the structural scenario and the parametric scenario. A structural scenario is a scenario that is carried out by changing the model structure on the variables that most influence the simulation objectives.

Meanwhile, the parametric scenario is a scenario that is carried out by changing the parameters of important variables to find out the possible conditions in the future, in optimistic, most likely and pessimistic condition categories. These scenarios were made to increase the potential for tourism in Pramuka Island based on the influencing factors.

Scenario 1 - Structural: Premium Assistance. Premium is an important variable in insurance, and the size of a premium must be a consideration for actors who will use insurance services, referring to fishermen in this study. The determination of premium assistance either carried out by the government and/or provided by the insurance service is related to the number of claims and the value of benefits provided so that it will affect the insurance offer provided to targeted consumers, referring to fishermen in this study. Scenario 2 Structural: Fisherman's Value. The fisherman's value that the researchers use is the net value of the fisherman exchange rate, so there is no income outside of sea products (such as gardening and so on). The income of fishermen, based on field results, is influenced by: the catch, capture fisheries business development, institutions, and multiplier effects. The exchange rate of fishermen is also influenced by what is issued by the fishermen. The influencing variables are: consumption value, education costs, entertainment costs and the value of investment/savings they set aside.

Parametric Scenario 1 - Optimistic: Changing the value of the influencing variable to the maximum growth value. Parametric Scenario 2 - Most Likely: Changing the value of the influencing variable to the average growth value. Parametric Scenario 3 - Pessimistic: Changing the value of the influencing variable to the minimum growth value. The results of the structural and parametric scenarios are presented in Table 3 below.

Table 3. Results of the Value of Structural and Parametric Scenarios.

\begin{tabular}{ll}
\hline Scenario & Insurance Demand (fishermen) \\
\hline Scenario 1 - Structural: Premium Assistance & 602 \\
Scenario 2 - Structural: Fisherman's Value & 394 \\
Parametric Scenario 1 - Optimistic & 578 \\
Parametric Scenario 2 - Most Likely & 289 \\
Parametric Scenario 3 - Pessimistic & 201 \\
\hline
\end{tabular}

The most common analysis used to The explanation from Table 3 of each scenario has been explained previously and based on the tabulation of the results of the scenario in Table 3 , it is shown that the insurance demand for $\geq 500$ fishermen is noted in Scenario 1 Structural: Premium Assistance 
(insurance demand of 602 fishermen) and Parametric Scenario 1 - Optimistic (fisherman insurance demand of 578 fishermen).

\section{The Projection of Demands for Fisherman Insurance in 2021-2029}

The projection of the number of demands of fisherman insurance is carried out to assess whether, based on the data obtained, the existing government programs and the socialization that has been carried out by Jasindo have an optimum impact following the targets planned by the government.

Table 4. The Projection of the Demands for Fishermen Insurance in 2021-2029.
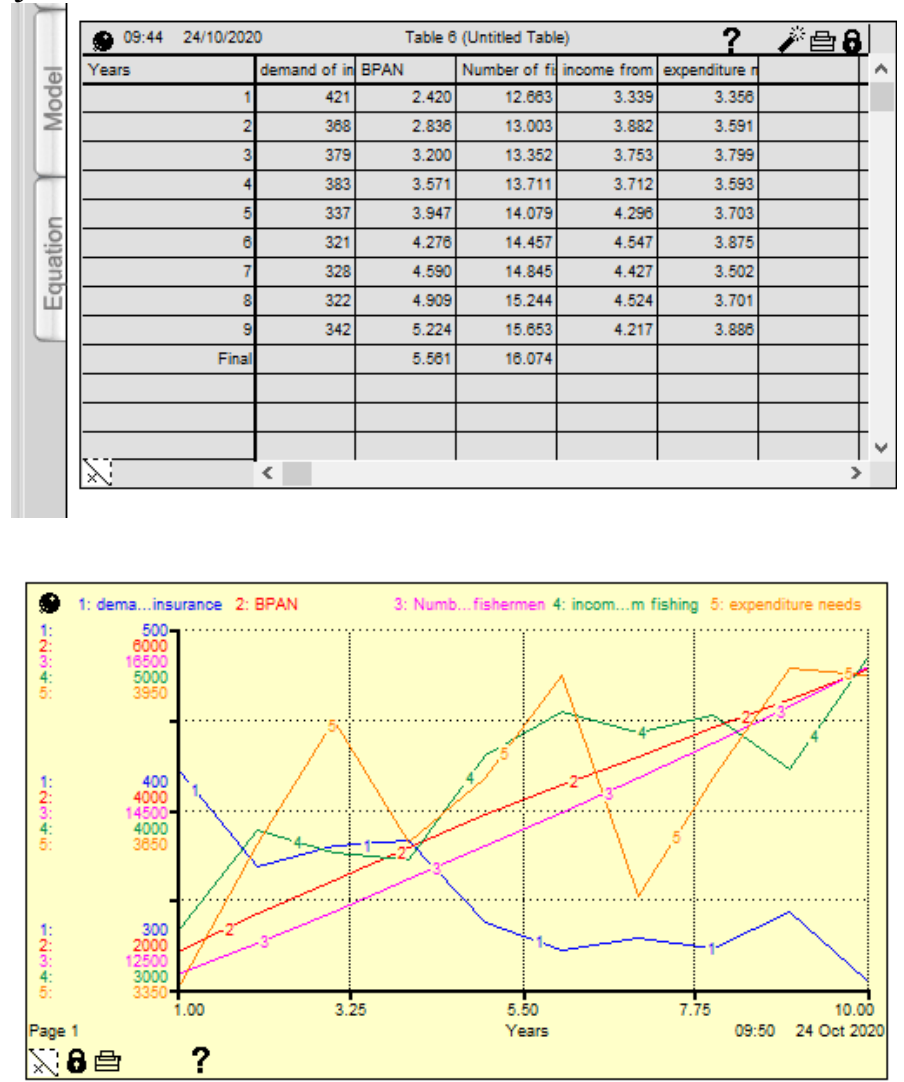

Figure 6. The Projection of Fishermen Insurance Demand 2021-2029.

Table 4 and Figure 6 are the results of the projection for the years 2021-2029 based on the field conditions. The results show that the number of demands for fisherman insurance in the nine-year projection is less than 500 , although the government's target with the socialization and programs offered by Jasindo, the government believes, will be able to achieve a figure of 500 or more but based on field results the conditions experience a fluctuation.

The field data of Malang Regency 2020 show that in 2016 the demand for insurance was 565 fishermen, and this was the beginning of a new program where certain people saw the uniqueness and benefits of the program, but the socialization programs by Jasindo serving as an insurance service provider, in this case, were not optimally carried out. In 2017, there were 1,079 fishermen demands for insurance, and in this second year, the socialization and education programs on the importance of fishermen insurance began to be intensively and routinely carried out by Jasindo and received full support from the Malang Regency government so that the number increased drastically above the government's target. In the following years, there was a decrease into 662 
fishermen in 2018 and a drastic decline occurred again in the following year 2019, with only 114 fishermen. Thus, from this description and some of the social and economic conditions of the community, researchers feel the need to predict the number of demands for fishermen insurance using systems and programs that have already been owned by the government and Jasindo.

Based on the field conditions, the results of the projection for the next nine years have not shown a minimum number of 500. Thus, it is necessary to forecast using several simulations which will be able to achieve the target of at least 500 fishermen each year.

\section{Simulation of the Projection of Fisherman Insurance Demand to Achieve Government Targets}

In this section, several simulations were carried out to obtain results where the demand for insurance can reach the government's target (minimum of 500). After several simulations were carried out, the researchers found that the most feasible simulation which has a significant and stable effect on the results desired by the government is through premium assistance. Table 5 and Figure 7 show that the simulation was carried out by providing insurance premium assistance every year of at least Rp. 118,000x109 will be able to produce a fisherman insurance demand figure at a minimum of 500 .

Table 5. Simulation of the Projection of Fisherman Insurance Demand.
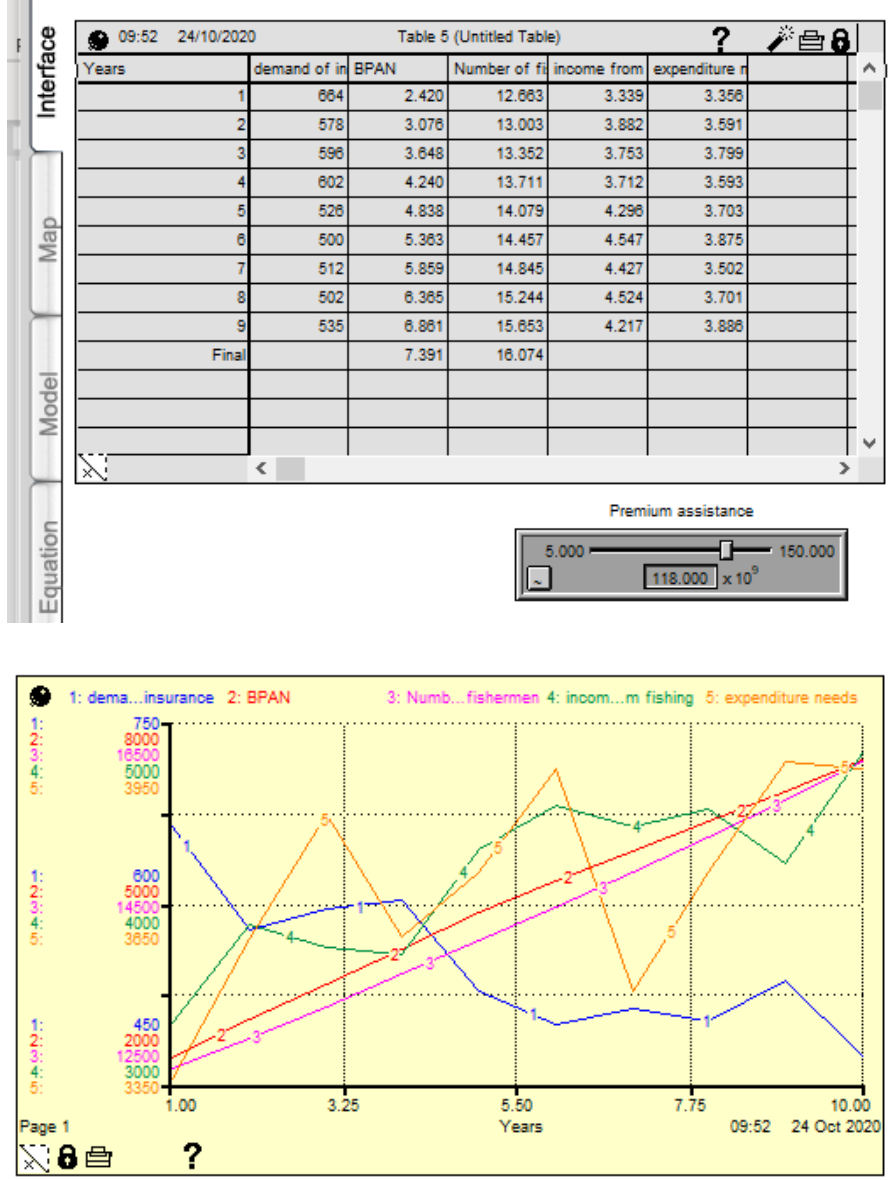

Figure 7. The Projection of Demands for Fisherman Insurance.

\section{CONCLUSION}

The projection of the demand for fishermen's insurance in 2021-2029 has not shown the results expected by the government. After several simulations, the study found the most possible simulation to be carried out and to have a significant, stable effect on the results desired by the 
government, which is through premium assistance. Based on the results of the simulation, if at least insurance premium assistance of Rp. 118,000x109 can be given annually, it will be able to generate a fisherman insurance demand at a minimum of 500 .

\section{ACKNOWLEDGMENT}

The researchers would like to express great gratitude to LPPM Universitas Brawijaya, HPP Program 2020. The researchers would also thank all respondents, DKP Malang for the assistance of secondary data, and all parties who have helped the smooth accomplishment of this research during the Covid19 Pandemic.

\section{REFERENCES}

Barlas, Y., 1989. Multiple tests for validation of system dynamics type of simulation models. European Journal of Operational Research, 42(1), pp.59-87. https://doi.org/1 0.1016/0377-2217(89)90059-3

Coyle, R.G., 1997. System dynamics modelling: a practical approach. Journal of the Operational Research Society, 48(5), pp.544-544. https:/ /doi.org/10.1057/palgrave.jors.2 600682

Forrester, J.W., 1999. System dynamics: the foundation under systems thinking. Sloan School of Management. Massachusetts Institute of Technology, 10.

Kiani, B., Gholamian, M.R., Hamzehei, A. and Hosseini, S.H., 2009. Using causal loop diagram to achieve a better understanding of e-business models. International Journal of Electronic Business Management, VII(3), pp.159-167. http://www.samamsystem.com/w p-content/uploads/2019/03/usin g_causal_loop_diagram.pdf

Law of the Republic of Indonesia Number 7, Article 3 of 2016. Perlindungan dan pemberdayaan nelayan, pembudidaya ikan, dan petambak garam.

Marine and Fisheries Department of Trenggalek Regency, 2019. Nilai tukar nelayan Kabupaten Trenggalek tahun 2019. LPPM UB. Trenggalek.

Muhammadi, Aminullah, E. and Soesilo, B., 2001. Analisis sistem dinamis : Lingkungan hidup, sosial, ekonomi, manajemen. UMJ Press. Jakarta.

Nuhoğlu, H. and Nuhoglu, M., 2007. System dynamics approach in science and technology education. Journal of Turkish Science Education, 4(2), pp.91-108. http://www.tused.org/index.php/ tused/article/view/674

Richardson, G.P. and Pugh III, A.L., 1997. Introduction to system dynamics modeling with DYNAMO. Journal of the Operational Research Society, 48(11), p.1146. https://doi.org/1 0.1057/palgrave.jors.2600961

Rusman, I.Y.S., 2016. Bab I : Sejarah dan perkembangan asuransi. https://w ww.aca.co.id/cmsprd/uploads/C 101\%20Sejarah\%20dan\%20Perke mbangan\%20Asuransi\%20150466 7223.pdf

Rusman, I.Y.S., 2018. Pengantar Asuransi. https://www.aca.co.id/cmsprd/u ploads/180110PengantarAsuransi \%201539051730.pdf

Sterman, J.D., Rebecca, H., Beinhocker, E.D. and Newman, L.I., 2007. Getting big too fast: Strategic dynamics with increasing returns and bounded rationality. Management Science, 53(4), pp.683-696. https://doi.org/10.12 87/mnsc.1060.0673

Suryani, E., Chou, S.Y., Hartono, R. and Chen, C.H., 2010. Demand scenario analysis and planned capacity expansion: A system dynamics framework. Simulation Modelling Practice and Theory, 18(6), pp.732-751. https://doi.org /10.1016/j.simpat.2010.01.013 
Sushil, 1993. System Dynamics : A Practical Approach for Managerial Problems. New Delhi : Wiley Eastern Limited.

Wati, L.A. and Primyastanto, M., 2018. Ekonomi Produksi Perikanan dan Kelautan Modern: Teori dan Aplikasinya. Malang : Universitas Brawijaya Press.

Wolstenholme, E.F., 1989. System dynamics research. University of Bradford: Sage Publication. Bradford.

Yuen, F.T. and Chan, S.L., 2010. System dynamics modelling in CRM: window fashions gallery. International Journal of Engineering Business Management, 2(2), pp.7784. https://doi.org/10.5772\%2F97 19 